Jurnal Kesehatan Reproduksi

Vol. 7 No. 3 - Desember 2020

ARTIKEL PENELITIAN

ISSN 2302-836X (print), ISSN 2621-461X (online)

Tersedia online di https://jurnal.ugm.ac.id/jkr

DOI: $10.22146 / j k r .59838$

\title{
Mitos dan Pengetahuan Masyarakat Desa Tentang Kanker Payudara
}

\author{
Atik Triratnawati ${ }^{1}$, Dewi Novyantari ${ }^{2}$ \\ 1,2Departemen Antropologi, Fakultas Ilmu Budaya, Universitas Gadjah Mada \\ Korespondensi: atik_triratnawati@yahoo.co.id/atik-tri@ugm.ac.id; dewinovyantari@gmail.com
}

Submisi: 17 September 2020; Revisi: 18 Januari 2021; Penerimaan: 22 Januari 2021

\begin{abstract}
Background: Breast cancer is a scary disease among the society. Myths related to breast cancer that still exist in society will affect their preventive behavior. Breast cancer myths is developed in the society with many varieties. So the knowledge level about breast cancer is variety also.

Objective: To identify the knowledge and myths in society about breast cancer.

Method: This explaratory study used participatory observation and in-depth interviews with 12 informants consisting of 3 breast cancer patients and 9 non-breast cancer survivors in Jlegiwinangun Village, Kutowinangun, Kebumen, Central Java.

Results and Discussion: The villager women have limited knowledge related to breast cancer. Breast cancer information has only from mouth to mouth. The information from the health personel has very rare. Breast cancer was considered a frightening disease that can be caused by heredity, eating patterns, and unhealthy behavior. The breast cancer myths exist, such as: unbreast feeding women, food and beverage preservative, bra wire, scalpel, risk for women age 30-50, which dispread verbally is indicated that myths is important . Myths is also as preventive behavior. unbreast feeding Conclusion: Knowledge about breast cancer among the women villager is limited, but the myths of breast cancer such as: unbreast feeding women, food and beverage preservative, bra wire, scalpel, risk for women age 30-50 are exist in the community. The myths is a part of preventive behavior.
\end{abstract}

Kata kunci: myths; community knowledge; village; breast cancer

\section{ABSTRAK}

Latar Belakang: Kanker payudara merupakan penyakit yang ditakuti. Mitos terkait kanker payudara masih ada di masyarakat yang berpengaruh terhadap perilaku dalam pencegahan. Mitos terkait kanker payudara yang berkembang di masyarakat cukup banyak ragamnya. Demikian juga tingkat pengetahuan masyarakat tentang kanker payudara juga bervariasi.

Tujuan: untuk mengidentifikasi pengetahuan dan mitos tentang kanker payudara yang berkembang di masyarakat desa.

Metode: Studi eksploratori menggunakan metode observasi partisipasi dan wawancara mendalam dilakukan terhadap 12 informan perempuan (3 penderita dan 9 non penderita) dari Desa Jlegiwinangun, Kutowinangun, Kebumen, Jawa Tengah.

Hasil dan Pembahasan: Pengetahuan perempuan desa terkait kanker payudara masih terbatas. Informasi tentang kanker payudara hanya dari mulut ke mulut. Informasi yang berasal dari petugas kesehatan jarang dilakukan. Kanker payudara dianggap penyakit menakutkan yang dipercaya akibat faktor keturunan, pola makan, dan perilaku hidup yang tidak sehat. Pengetahuan terkait mitos justru berkembang seperti perempuan tidak menyusui, konsumsi makanan minuman berpengawet, pemakaian BH berkawat, usia perempuan 30-50 tahun berisiko, pisau bedah akan menyebarkan kanker, yang diperoleh secara lisan menunjukkan bahwa masyarakat menganggap mitos itu penting. Mitos itu sekaligus sebagai cara untuk pencegahan.

Kesimpulan: Pengetahuan perempuan desa tentang kanker payudara sangat terbatas, namun, mitos-mitos terkait kanker payudara seperti perempuan tidak menyusui, konsumsi makanan berpengawet, $\mathrm{BH}$ berkawat, usia 30-50 tahun, pisau bedah berkembang di masyarakat. Pengetahuan tentang mitos kemudian dipakai sebagai cara mereka mencegah kanker payudara.

Kata kunci: mitos; pengetahuan masyarakat; desa; kanker payudara 


\section{PENDAHULUAN}

Sehat dan sakit merupakan kondisi tubuh manusia yang tidak dapat diprediksi kejadiannya tetapi manusia pasti mengalaminya. Seseorang menjadi sehat atau sakit sering kali dianggap akibat perilakunya sendiri. ${ }^{1}$ Pola makan yang kurang sehat dan kurangnya aktivitas fisik merupakan salah satu penyebab pada penyakit tidak menular. Karena itu meningkatnya produksi makanan cepat saji serta gaya hidup yang tidak sehat membuat seseorang rentan terserang berbagai jenis gangguan kesehatan, salah satunya adalah kanker. ${ }^{1}$

Dewasa ini jumlah penderita kanker di seluruh dunia terus meningkat secara signifikan. Bahkan penyakit kanker menjadi salah satu penyebab kematian utama di seluruh dunia. Penyakit kanker merupakan penyakit yang timbul akibat pertumbuhan sel jaringan tubuh yang tidak normal di luar batas biasanya yang kemudian dapat menyerang bagian tubuh yang berdampingan dan/atau menyebar ke organ lain. ${ }^{2}$ Lebih dari $30 \%$ kematian akibat kanker disebabkan oleh lima faktor risiko perilaku dan pola makan yaitu indeks massa tubuh tinggi, kurang konsumsi buah dan sayur, kurang aktivitas fisik, penggunaan rokok, dan konsumsi alkohol berlebihan. ${ }^{3}$ Sumber lain menambahkan fast food atau junk food sebagai penyebab utama kanker payudara. ${ }^{4} \mathrm{Di}$ Indonesia, kanker payudara merupakan jenis penyakit kanker yang paling sering ditemukan pada perempuan dan merupakan penyebab kematian utama akibat kanker pada perempuan. Data Riskesdas 2018 menyatakan bahwa prevalensi kanker payudara mencapai 1,79 per 1.000 penduduk, naik dari 2013 yaitu 1,4/1.000 penduduk. $^{5}$ Angka kejadian kanker payudara di Indonesia yaitu sebesar 42,1 per 100.000 penduduk dengan rata-rata kematian 17 per 100.000 penduduk. Untuk pencegahan dan pengendalian kanker di Indonesia, khususnya kanker payudara, pemerintah telah melakukan berbagai upaya antara lain deteksi dini kanker payudara pada perempuan 30-50 tahun dengan menggunakan metode Pemeriksaan Payudara Klinis (SADANIS). ${ }^{6}$

Pemeriksaan payudara sendiri (SADARI) juga dapat dilakukan untuk menurunkan angka kematian akibat kanker payudara dengan penemuan sedini mungkin dan pengobatan saat ukuran masih kecil sebelum kanker tersebut bermetastasis. ${ }^{7}$ Namun sejumlah perempuan enggan melakukan periksa payudara sendiri karena takut ketahuan kanker, tidak tahu caranya, serta tidak ada tanda dan gejala kanker. ${ }^{8}$ Dengan deteksi dini kanker payudara dapat menekan angka kematian sebesar $25-30 \%{ }^{8,9}$ Kanker payudara yang diobati pada stadium dini kemungkinan sembuh mendekati $95 \% .{ }^{10}$ Lebih dari $80 \%$ kasus kanker payudara di Indonesia ditemukan berada pada stadium yang lanjut, dimana upaya pengobatan akan lebih sulit dilakukan. Para ahli menyatakan $40 \%$ kanker dapat dicegah dengan mengurangi faktor risiko. ${ }^{11}$ Padahal kanker payudara yang disadari sejak dini memiliki kemungkinan untuk mendapatkan penanganan yang lebih baik. Faktor-faktor penyebab penderita kanker payudara menunda pengobatan medis diantaranya adalah faktor psikologis, kurangnya pengetahuan, mitos, budaya, terhambatnya komunikasi dengan dokter, pelayanan kesehatan, biaya, keterbatasan fasilitas, dan hanya melakukan doa saja. ${ }^{12}$

Beragam mitos mengenai kanker payudara banyak muncul dan berkembang di tengah masyarakat. Mitos tersebut tidak sepenuhnya benar namun perlu untuk ditelusuri kebenarannya. Beberapa mitos seputar kanker payudara yang dipercayai yaitu benjolan pada payudara berarti terkena kanker payudara, pria bebas dari kanker payudara, mamogram dapat menyebabkan kanker payudara menyebar, jika keluarga ada yang terkena kanker payudara maka juga akan terkena kanker payudara, anti-perspirant dapat menyebabkan kanker payudara, penderita tumor di payudara ketika menyusui akan meningkatkan risiko kanker pada anaknya, kanker payudara dapat disebabkan oleh adanya luka di payudara, perempuan berpayudara kecil tidak berisiko terkena kanker payudara, pemeriksaan payudara mencegah kanker payudara, kanker payudara terutama menyerang perempuan berusia antara 30 sampai 50 tahun. $^{13}$

\section{METODE}

Penelitian ini menggunakan pendekatan studi kualitatif, dengan metode eksploratif yang dilakukan di Desa Jlegiwinangun, Kutowinangun, Kebumen, Jawa Tengah. Lokasi tersebut dipilih karena terdapat 
3 penderita kanker payudara yang tinggal di desa itu sehingga asumsinya masyarakat setempat memiliki pengetahuan dan pengalaman terkait penyakit kanker payudara. Penelitian dilakukan selama 2 bulan yaitu bulan April dan September 2019 dengan cara peneliti tinggal bersama dengan warga masyarakat untuk mengamati keseharian hidup penderita kanker payudara dan lingkungannya.

Pengumpulan data dilakukan dengan cara partisipasi observasi dan wawancara mendalam terhadap 12 informan perempuan yang terdiri dari 3 penderita kanker payudara dan 9 masyarakat biasa (bukan penderita kanker payudara). Observasi dilakukan dengan mengamati dan memahami kondisi, lingkungan, serta kehidupan sehari-hari penderita kanker payudara maupun masyarakat sekitarnya. Sementara itu wawancara dilakukan dengan tujuan memahami pengalaman penderita kanker payudara maupun masyarakat dan bagaimana arti dari pengalaman mereka tersebut terkait penyakit kanker payudara. Selanjutnya proses analisis data dilakukan melalui transkrip, klarifikasi, koding dan matriks yang kemudian dianalisis menggunakan konsep-konsep dalam Antropologi Kesehatan.

Informan adalah perempuan penderita, keluarga, atau tetangga pasien kanker payudara usia reproduksi maupun lansia yang bersedia diwawancarai. Para informan mayoritas adalah perempuan yang berprofesi sebagai ibu rumah tangga dengan rentang usia 22 sampai 70 tahun dan jenjang pendidikan tingkat Sekolah Dasar sampai tingkat Sarjana.

\section{HASIL DAN PEMBAHASAN}

\section{Gambaran Kondisi dan Situasi Lingkungan Desa}

Desa Jlegiwinangun (atau sering disebut Jlegi) merupakan satu dari 19 desa yang ada di Kecamatan Kutowinangun dan merupakan wilayah yang terletak di bagian paling utara. Penduduk Desa Jlegiwinangun mayoritas bekerja sebagai karyawan swasta, petani, dan mengurus rumah tangga. Kebanyakan penduduknya berusia lanjut dengan jumlah pasangan usia subur kurang lebih 200 pasangan dari total jumlah penduduk 3.152 jiwa.
Pelayanan kesehatan di Desa Jlegiwinangun sudah tergolong memadai. Terdapat satu Poliklinik Kesehatan Desa (PKD) yang dilayani oleh satu tenaga bidan dan juga 4 Posyandu. Program-program kesehatan pun sering dilaksanakan oleh kader-kader desa demi meningkatkan taraf kesehatan masyarakat. Akses terhadap pelayanan kesehatan yang lengkap seperti Puskesmas dan rumah sakit juga dapat dijangkau dengan mudah. Jarak yang tidak begitu jauh kurang lebih 6 kilometer dan akses jalan yang mudah serta transportasi yang memadai memudahkan masyarakat untuk mendapatkan pelayanan kesehatan dengan baik.

\section{Subjek Penelitian}

Hasil penelitian menunjukkan bahwa para informan merupakan tetangga penderita kanker payudara di Desa Jegliwinangun, baik yang tinggal di depan, belakang, samping rumah penderita atau yang masih satu lingkungan RT yang sama. Tetangga penderita kanker payudara dipercaya lebih tahu keseharian penderita serta faham kapan sesorang itu mulai mengalami kanker payudara. Dari 12 informan dalam penelitian ini terdapat 3 informan yang merupakan penderita kanker payudara (yaitu I.1, I.2, I.3), satu informan yang merupakan keluarga (adik) penderita kanker payudara (yaitu I.4), dan 8 informan yang merupakan tetangga penderita kanker payudara (I.5, I.6, I.7, I.8, I.9, I.10, I.11, I.12). Usia para informan bervariasi yaitu 20-29 tahun, 1 orang, 30-39 tahun 3 orang, 40-49 tahun 3 orang, 50-59 tahun 3 orang, dan di atas 60 tahun 1 orang. Status pernikahannya adalah 11 menikah dan 1 orang belum menikah. Sementara jenjang pendidikannya adalah SD 1 orang, SMP 5 orang, SMA 2 orang, diploma 1 orang dan sarjana 1 orang. Pekerjaan informan mayoritas ibu rumah tangga (6), pedagang (2), pensiunan (2), pekerja lepas (1) dan mencari kerja (1). Dari latar belakang pekerjaan dan pendidikan yang dimiliki informan akan terlihat bagaimana pandangan mereka terkait pengetahuan dan mitos terkait kanker payudara.

\section{Pengetahuan}

Dari hasil observasi dan wawancara, diperoleh gambaran bahwa pengetahuan mereka tentang 
kanker payudara secara umum relatif terbatas, baik dalam hal penyebab, pengobatan dan pencegahan kanker payudara. Pendapat mereka tentang penyakit kanker payudara antara lain sebagai berikut:

"nggak tahu ... tahunya ya penyakit ... penyakit Allah yang kasih" (I.2)

"penyakit menakutkan" (I.12)

"sejenis benjolan yang sudah ganas di payudara ... kalau di sini termasuk penyakit yang mengerikan" (I.4)

Dari pernyataan beberapa informan di atas menunjukkan bahwa pengetahuan tentang kanker payudara relatif terbatas. Hal tersebut juga didukung oleh pernyataan salah satu informan yang sekaligus seorang kader kesehatan sebagai berikut:

"Kanker payudara dianggap masih penyakit langka, jadi orang-orang di sini kurang menaruh perhatian soal penyakit itu" (I.10)

Pengetahuan mengenai penyebab kanker payudara dari beberapa informan adalah sebagai berikut:

"Mungkin tidak menyusui apa ya ... kata orang jaman dulu kan karena air susu mengendap apa ya" (I.2)

"Tidak menyusui... harusnya ASI kan diberikan pada bayinya tetapi mengendap tidak dikeluarkan apa gimana ... terus jadi penyebab itu ... katanya sih gitu" (I.12)

"Keturunan mungkin ... pola makan kayak apa yang kita makan juga memengaruhi ... banyak MSG dan makanan cepat saji" (I.9)

"Faktor keturunan bisa ... bahan-bahan kimia yang dikonsumsi tidak aturan" (I.3)

"Pola makan ... pola hidup yang tidak sehat ... makanan yang instan-instan karena jaman sekarang suka yang praktis-praktis" (I.10)

Sebagian besar informan percaya bahwa penyebab kanker payudara diantaranya adalah ibu yang tidak menyusui sehingga terdapat benjolan yang disebabkan oleh air susu yang mengendap karena tidak diberikan kepada bayi. Faktor keturunan juga dimungkinkan, apabila ada keluarga sedarah yang terkena kanker sebelumnya maka bisa saja keluarga yang lain dapat terkena kanker. Selain itu pola makan yang tidak sehat yaitu konsumsi makanan dan minuman instan serta mengandung penyedap dan pengawet buatan.

Penyebab kanker payudara dianggap karena ibu tidak menyusui bayinya, serta ibu yang tidak memiliki. Hal ini didukung kasus yang dialami penderita kanker payudara 1.1 yang tidak memiliki anak sehingga para informan percaya hal tersebut dapat meningkatkan risiko kanker payudara. Mereka meyakini bahwa air susu yang tidak dikeluarkan atau tidak diberikan kepada bayi akan menggumpal di dalam payudara dan gumpalan tersebut akan memicu tumbuhnya benjolan yang menyebabkan kanker payudara.

4. Mitos dan Kepercayaan Tentang Kanker Payudara

Dalam kehidupan mereka sehari-hari, kepercayaan dan mitos mengenai kanker payudara masih dikenal. Keberadaan mitos diketahui beredar dari mulut ke mulut. Bagi orang luar desa mitos tersebut dianggap tidak cukup kuat untuk dipercaya, akan tetapi bagi warga setempat mereka melayakini dan mempercayainya. Ada beberapa mitos umum terkait kanker payudara, namun tidak semua informan mengenalinya. Mitos-mitos yang diketahui dari mulut ke mulut itulah yang mereka pahami, sementara yang di luar itu, seperti yang terdapat pada sumber tertulis seperti buku, internet tidak diketahui oleh para informan. Akibatnya beberapa mitos yang dikenal umum tidak semuanya mereka pahami. Mereka tidak pernah membaca sumber tertulis seperti koran, majalah karena tidak ada yang berlangganan koran atau majalah. Mereka mengetahui sesuatu informasi hanya dari mulut ke mulut seperti dari keluarga, tetangga, bidan, kader atau dokter. Mitos-mitos tersebut sekedar didengar dan diketahui, namun belum terlihat mempengaruhi cara berpikir, bertindak, mencegah serta berperilaku menghadapi kanker payudara.

Meskipun di desa terdapat tiga perempuan penderita kanker payudara akan tetapi 
informasi terkait kanker payudara yang lengkap tidak mereka pahami. Memang jika ada tetangga penderita kanker payudara berobat atau melakukan operasi para tetangga akan menjenguk dan memberi semangat pada si sakit. Akan tetapi pengetahuan yang terkait dengan kanker payudara secara utuh kurang mereka pahami. Bagi mereka penyakit kanker payudara kurang menjadi perhatiannya. Memang beberapa informan menyatakan dulu ada juga pasien kanker payudara yang telah meninggal, tetapi peristiwa itu sudah berlalu lama, sehingga tidak semuanya mampu mengingatnya. Mereka berpikir tidak akan mengalami penyakit tersebut sehingga penyakit itu terabaikan. Pengetahuan mengenai risiko juga kurang difahami. Hal ini didasari pengetahuan mereka bahwa di desa ini yang terkena kanker payudara itu hanya sedikit, hanya hitungan jari.

Adanya mitos tentang kanker payudara yang ada di tengah-tengah masyarakat mungkin membuat masyarakat lebih bersikap hati-hati. Artinya aspek pencegahan bisa saja mereka lakukan, terutama perilaku yang mudah untuk dilakukan. Namun, dari terbatasnya mitos yang mereka ketahui dapat berakibat pola-pola pencegahan yang mereka lakukan akan terbatas jumlahnya. Sedikitnya jumlah mitos atau kepercayaan lokal mengenai kanker payudara didukung oleh pernyataan informan sebagai berikut:

"Orang desa kan tidak pernah cerita-cerita soal penyakit, jadi biasa saja soal kanker payudara tidak pernah jadi pembicaraan." (I.9)

Selanjutnya, seluruh informan diberikan beberapa pertanyaan terkait mitos umum tentang kanker payudara yang paling sering ditemukan di Indonesia. Mitos itu seperti: benjolan pada payudara berarti terkena kanker payudara, pria bebas dari kanker payudara, mamogram dapat menyebabkan kanker payudara menyebar, jika keluarga ada yang terkena kanker payudara maka juga akan terkena kanker payudara. Selain itu deodoran, anti-perspirant dapat menyebabkan kanker payudara. Ada pula mitos penderita tumor di payudara ketika menyusui akan meningkatkan risiko kanker pada anaknya, kanker payudara dapat disebabkan oleh adanya luka di payudara, perempuan berpayudara kecil tidak berisiko terkena kanker payudara. Dalam hal terapi pengobatan juga muncul mitos bahwa pemeriksaan payudara mencegah kanker payudara, kanker payudara terutama menyerang perempuan berusia antara 30 sampai 50 tahun, perempuan perawan/tidak menyusui berisiko terkena kanker payudara. Juga ada mitos perempuan dengan jumlah anak sedikit berisiko terkena kanker payudara, pemakaian breast-holder (BH) berkawat dapat menyebabkan kanker payudara, pemakaian cat rambut dapat menyebabkan kanker payudara, penggunaan ponsel dapat menyebabkan kanker payudara, konsumsi terhadap makanan dan minuman yang mengandung zat pengawet dapat menyebabkan kanker payudara, suntik dokter dapat menyebabkan kanker menyebar, dan pisau dokter/bedah dapat menyebabkan kanker menyebar.

Dari sejumlah mitos di atas hanya sebagian kecil yang dipercaya oleh para informan. Mitos yang banyak didengar dan diketahui para informan yaitu:

1. Perempuan yang tidak menyusui berisiko terkena kanker payudara. Seluruh informan yang diwawancara menyebutkan bahwa mereka mengetahui tentang hal tersebut. Hal itu dimungkinkan karena berhubungan dengan kasus yang terjadi pada salah satu penderita kanker payudara I.1 yang tidak memiliki anak ditambah kasus lain yang juga tidak memiliki anak tetapi penderita itu sudah meninggal dunia.

2. Konsumsi terhadap makanan dan minuman yang mengandung zat pengawet dapat menyebabkan kanker payudara merupakan mitos kedua yang paling diketahui oleh para informan. Dari 12 informan hanya satu informan yang mengatakan bahwa ia tidak pernah mengetahui bahwa konsumsi terhadap makanan dan minuman yang mengandung zat pengawet dapat menyebabkan kanker payudara.

3. Mitos lain yang paling diketahui adalah soal pemakaian breast-holder berkawat yang dapat 
menyebabkan kanker payudara. Delapan dari 12 informan mengatakan bahwa mereka mengetahui pemakaian breast-holder berkawat yang dapat menyebabkan kanker payudara. Seperti dikemukakan oleh informan I.4:

"Saya percaya bahwa BH berkawat jika dipakai akan menyebabkan peredaran darah tidak lancar dan mempengaruhi terjadinya kanker payudara."

4. Bentuk payudara besar maupun kecil yang dimiliki perempuan semua berisiko terkena kanker payudara. Mereka percaya bahwa penyebab kanker payudara itu virus yang akan menyebar, sehingga semua perempuan dengan bentuk payudara apapun dapat mengalaminya. Seperti diutarakan I.11 berikut:

"Payudara besar atau kecil semua berisiko karena kanker payudara itu disebabkan virus yang akan menyebar ke seluruh tubuh."

5. Pisau bedah yang dipergunakan dokter untuk melakukan operasi dipercaya dapat menyebarkan penyakit ini.

6. Mitos lain yaitu kanker payudara hanya akan dialami perempuan yang berumur $30-50$ tahun.

Mitos-mitos yang kurang diketahui oleh para informan diantaranya mengenai benjolan pada payudara berarti terkena kanker payudara. Hanya dua dari seluruh informan mengetahui dan percaya atas mitos tersebut. Hanya satu informan yang mengetahui dan percaya bahwa pria bebas dari kanker payudara. Sisanya tidak faham bila pria juga berisiko terkena kanker payudara. Dua informan mengetahui mitos bahwa anti-perspirant atau deodorant dapat menyebabkan kanker payudara. Penderita kanker di payudara ketika menyusui akan meningkatkan risiko kanker pada anaknya hanya diketahui oleh satu orang informan. Tiga informan menyebutkan bahwa mereka mengetahui tentang kanker payudara dapat disebabkan oleh adanya luka di payudara. Mitos mengenai perempuan yang berpayudara kecil tidak berisiko terkena kanker payudara hanya diketahui oleh satu orang informan. Masing-masing lima orang informan mengetahui mitos bahwa perempuan dengan jumlah anak sedikit berisiko terkena kanker payudara serta pemeriksaan payudara dapat mencegah kanker payudara. Tiga dari 12 informan mengetahui dan percaya bahwa kanker payudara terutama hanya menyerang perempuan berusia 30-50 tahun. Dua informan menyatakan bahwa mereka mengetahui jika penggunaan ponsel dapat menyebabkan kanker payudara. Mitos bahwa pisau dokter/bedah dapat menyebabkan kanker menyebar, lima dari seluruh informan menyatakan bahwa mereka mengetahui dan percaya akan mitos tersebut.

Mitos yang sama sekali tidak diketahui oleh kedua belas informan adalah mengenai mamogram dapat menyebabkan kanker menyebar, pemakaian cat rambut dapat menyebabkan kanker payudara, dan suntik dokter dapat menyebabkan kanker menyebar. Mereka yang mengetahui mitosmitos tersebut menyebutkan bahwa mereka mendengar berbagai informasi mengenai mitos yang mereka ketahui melalui pengalaman mereka sendiri, tetangga, media sosial, dan televisi. Warga masyarakat yang berumur lebih muda dan berpendidikan cukup dipercaya lebih 'melek' terhadap informasi mengenai kanker payudara. Informan dengan usia yang lebih muda memiliki akses teknologi yang lebih canggih sehingga adanya akses terhadap informasi mengenai kanker payudara lebih mudah mereka dapatkan.

\section{PEMBAHASAN}

\section{Pengetahuan tentang Kanker Payudara}

Di dalam studi antropologi kesehatan terdapat dua kategori sistem medis yaitu yang bersifat personalistik dan naturalistik. Sistem personalistik adalah suatu sistem di mana penyakit disebabkan oleh intervensi dari suatu agen yang aktif, yang dapat berupa makhluk supranatural (makhluk gaib atau dewa), makhluk bukan manusia (seperti hantu, roh leluhur, atau roh jahat), maupun makhluk manusia (tukang sihir atau tukang tenung). Sementara dalam sistem naturalistik, penyakit dijelaskan dengan istilah-istilah sistemik yang bukan pribadi. Dalam sistem naturalistik, sehat terjadi karena unsur-unsur yang tetap atau seimbang dalam tubuh, apabila keseimbangan terganggu maka hasilnya adalah timbulnya penyakit. ${ }^{14}$ 
Definisi tentang penyebab sakit atau penyakit pada setiap masyarakat tidaklah sama, mereka mendefinisikan penyakit secara lokal yang disesuaikan dengan pengalaman dan pemahaman mereka terhadap suatu penyakit sehingga masyarakat medefinisikan penyakit dalam cara yang berbeda-beda. Masyarakat Jlegiwinangun memiliki pemahaman bahwa penyakit kanker payudara disebabkan oleh faktor yang bersifat naturalistik. Penyebab kanker payudara dianggap bukan karena pengaruh agen-agen supranatural, kekuatan-kekuatan ghaib, atau tindakan-tindakan yang tidak dapat diketahui dengan pasti seperti dukun dan santet. Kanker payudara dianggap suatu penyakit yang memiliki penyebab bersifat nonsupranatural yang disebabkan karena pengaruh hal-hal yang yang dapat diketahui dengan pasti berdasarkan hubungan sebab-akibat seperti pola makan, makanan-minuman instant yang berpengawet, faktor keturunan, perilaku hidup tidak sehat (tidak seimbang), ataupun hal yang lain yang bisa diamati. Pemahaman terkait makanan ini sesuai dengan pendapat dr. Marc Lippman dari Georgetown University yang menyebut fast food adalah pemicu utama kanker payudara. Dalam makanan instan terkandung lemak dan kalori yang tinggi. ${ }^{15}$ Sementara alat kontrasepsi juga dipercaya perempuan desa sebagai penyebab kanker payudara. Hal ini didukung hasil penelitian lain yang menunjukkan bahwa perempuan yang memakai alat kontrasepsi hormonal selama $\geq 5$ tahun berisiko terkena kanker payudara 3,266 kali lebih besar dibanding dengan perempuan yang memakai alat kontrasepsi hormonal selama $<5$ tahun. ${ }^{16}$

Dalam perilaku pencegahan kanker payudara, sikap informan pada umumnya masih menganggap bahwa pencegahan dan deteksi dini belum terlalu penting karena mereka merasa dirinya sehatsehat saja, tidak ada tanda-tanda dan gejala, serta merasa tidak memiliki faktor risiko. Padahal faktor risiko kanker payudara terjadi pada semua perempuan, usia lebih dari 50 tahun, riwayat keluarga dan genetik, riwayat penyakit payudara sebelumnya, riwayat menstruasi dini (kurang dari 12 tahun), menarche-menopause lambat (lebih dari 55 tahun), tidak memiliki anak, tidak menyusui, hormonal, kegemukan, konsumsi alkohol, riwayat radiasi dinding dada, dan faktor lingkungan. ${ }^{17,18}$ Faktor riwayat keluarga ini penting sebagai upaya promosi kesehatan, sebab secara medis risiko kanker payudara pada wanita dengan ibu dan saudara perempuan terkena kanker payudara akan meningkatkan risiko keganasan. ${ }^{19}$ Sebaliknya jika tidak memiliki riwayat keluarga akan aman. ${ }^{20}$

Menurut Kementrian Kesehatan RI dalam Panduan Penatalaksanaan Kanker Payudara, pencegahan dan deteksi dini terhadap kejadian kanker payudara dapat dilakukan melalui pencegahan primer dan pencegahan sekunder. Pencegahan primer adalah usaha agar tidak terkena kanker payudara berupa mengurangi dan meniadakan faktor-faktor risiko yang diduga sangat erat kaitannya dengan peningkatan kejadian kanker payudara. Pencegahan sekunder adalah dengan melakukan pemeriksaan berupa Periksa Payudara Sendiri (SADARI), Periksa Payudara Klinis (SADANIS), dan mammografi. Pencegahan terjadinya kanker payudara secara sederhana dapat dilakukan dengan mengetahui sebanyak-banyaknya tentang faktor risiko kanker payudara lalu berusaha menghindarinya. ${ }^{11}$

Dalam memperoleh kesembuhan, proses mencari pengobatan untuk kanker payudara terlihat berbagai pola yang ada. Pola tersebut termasuk ke dalam suatu perilaku pencarian pelayanan kesehatan (health seeking behavior) yang meliputi tindakan yang diambil seseorang untuk memperoleh penyebuhan atau terlepas dari masalah kesehatan yang dideritanya baik di fasilitas kesehatan modern maupun tradisional. ${ }^{21}$ Dalam pemilihan layanan kesehatan oleh penderita kanker payudara di Desa Jlegiwinangun dalam mendapatkan penyembuhan sangatlah beragam. Ketiga penderita payudara memilih fasilitas kesehatan modern seperti dokter keluarga dan rumah sakit ketika pertama kali mereka merasakan gejala pada payudara mereka. Setelah didiagnosa oleh dokter mengalami gejala kanker payudara, tidak semua penderita kanker payudara memilih pengobatan di fasilitas kesehatan modern. Ada yang memilih langsung ke fasilitas kesehatan modern seperti rumah sakit, ada yang memanfaatkan fasilitas kesehatan tradisional seperti ke tabib dan orang pintar, sebelum akhirnya memutuskan untuk melakukan 
pengobatan di fasilitas kesehatan modern karena di fasilitas kesehatan sebelumnya tidak mendapatkan kesembuhan. Situasi menunjukkan bahwa sulit bagi pasien menentukan pilihan pengobatan sendiri tanpa mempertimbangkan orang lain. Karakteristik masyarakat Indonesia umumnya bersifat kolektif sehingga keputusan yang dianggap penting harus bersadar kesepakatan bersama, peran suami dan kerabat cukup menentukan. ${ }^{22}$ Faktor budaya terlihat perannya yaitu bagaimana masyarakat merespon sakit dan rasa nyeri pada kanker payudara dengan cara yang berbeda. ${ }^{23}$

Pengalaman menjadi hal yang sangat penting bagi masyarakat Desa Jlegiwinangun. Berangkat dari pengalaman para penderita kanker payudara maka selanjutnya di dalam masyarakat terbentuklah suatu pengetahuan mengenai penyakit kanker payudara. Kesadaran akan penyakit kanker payudara sangat dipengaruhi oleh pengetahuan dan pengalaman individu. Mereka yang memiliki pengalaman sendiri akan memiliki lebih banyak pengetahuan tentang kanker payudara daripada perempuan yang tidak memiliki pengalaman sendiri terkait penyakit kanker payudara. Pengalaman sendiri yang dimaksud adalah pengalaman sebagai penderita kanker payudara atau pengalaman dari saudara terdekat yang mengalami kanker payudara. Pengetahuan yang dimiliki masingmasing individu akan mempengaruhi bagaimana perempuan di Desa Jlegiwinangun menyikapi penyakit kanker payudara. Namun pengetahuan terhadap kanker payudara tersebut belum dapat mendorong perubahan perilaku pencegahan dan deteksi dini kanker payudara.

\section{Pengaruh Mitos Terhadap Perilaku Pencegahan dan Penyembuhan Kanker Payudara}

Mitos-mitos mengenai kanker payudara yang banyak muncul dan berkembang di tengah masyarakat tidak selalu sepenuhnya dianggap benar. Perlu dilakukan berbagai cara untuk mengetahui kebenarannya. Hal ini tidak jarang masyarakat menganggap mitos tersebut benar-benar terjadi. Akan tetapi ada yang meragukan kebenaran mitos-mitos yang berkembang terkait penyakit kanker payudara ini karena sumber atau penelitian mengenai mitos tersebut belum lengkap atau bahkan tidak pernah ditemukan sebelumnya. Seringkali mitos-mitos tersebut muncul dan berkembang di masyarakat bertujuan untuk hal-hal yang baik supaya masyarakat lebih menjaga perilaku dan gaya hidupnya.

Ketika penderita kanker payudara di Desa Jlegiwinangun yang mengenal dan mempercayai mitos mengenai pengobatan kanker payudara seperti pisau dokter/bedah dapat menyebabkan kanker menyebar tidak lantas penderita takut untuk melakukan pengobatan medis di fasilitas kesehatan modern. Bagi masyarakat bukan penderita kanker payudara kebanyakan mengenal dan mempercayai terkait mitos jika keluarga ada yang terkena kanker payudara maka juga akan terkena kanker payudara, perempuan yang tidak menyusui berisiko terkena kanker payudara, pemakaian breast-holder berkawat dapat menyebabkan kanker payudara, dan konsumsi terhadap makanan dan minuman yang mengandung zat pengawet dapat menyebabkan kanker payudara.

Mitos-mitos yang dipercaya masyarakat setempat ada yang sesuai dengan pandangan ilmiah. Hampir seluruh informan mempercayai konsumsi terhadap makanan dan minuman yang mengandung zat pengawet dapat menyebabkan kanker payudara namun tidak ada dari mereka yang benar-benar meninggalkan konsumsi makanan dan minuman tersebut. Hal ini menunjukkan bahwa pengetahuan yang mereka miliki dan mereka percaya tidak sematamata selalu diikuti dengan perilaku pencegahan terhadap penyakit kanker payudara.

Pendapat umum tentang apa saja yang menyebabkan kanker payudara, cenderung masih banyak dipercayai oleh orang awam karena dianggap masuk akal. ${ }^{24}$ Demikian pula dalam hal mitos, tidak semua mitos tersebut merupakan fakta tapi bisa jadi hanya mitos semata. Akibatnya dengan adanya mitos dapat membentuk kekhawatiran yang tidak perlu. Namun, karena mitos di masyarakat desa ini berkembang dari mulut ke mulut maka kepercayaan mereka terhadap mitos tetap ada meskipun seakanakan mitos tersebut tidak berpengaruh atas perilaku mereka dalam pencegahan kanker payudara. Mitosmitos yang dikenal meski jumlahnya terbatas tetap relevan bagi masyarakat desa sebab secara tidak langsung seringkali mereka teringat akan mitos tersebut sehingga perilaku mereka berubah. Sebagai contoh perempuan desa tidak berani memakai $\mathrm{BH}$ berkawat karena takut terkena kanker payudara. 
Namun, ada alasan rasional lain yang mereka jelaskan bahwa BH berkawat itu biasa dipakai orang kota, sehingga mereka merasa sebagai orang desa sehingga tidak perlu memakai BH berkawat.

Terbatasnya arus informasi terkait kanker payudara mengakibatkan pengetahuan dan pemahaman akan mitos sangat terbatas. Meski di desa terdapat sejumlah penderita kanker payudara termasuk mereka yang sudah meninggal dunia akibat penyakit tersebut akan tetapi tidak mampu mengubah perilaku warga dalam pencegahan. Pihak pamong desa, kader kesehatan, PKK, Puskesmas sebagai pihak yang bertanggungjawab atas promosi kesehatan belum mampu berperan penuh dalam penyuluhan dan sosialisasi program pencegahan kanker payudara. Faktor kesibukan bekerja para perempuan, sulitnya mencari informasi terkait kander payudara maupun tidak ada niat untuk mencari informasi karena keterbatasan tingkat pengetahuan dan pendidikan mereka menjadi penghambat perubahan perilaku sehat. Kepemilikan hand phone (HP) diantara perempuan desa tidak difungsikan guna mencari informasi kesehatan mengingat HP sekedar difungsikan untuk komunikasi dan hiburan semata. Keterbatasan kemampuan ekonomi dan rendahnya tingkat literasi dalam bidang kesehatan bisa jadi menjadi faktor internal mengapa masyarakat di Desa Jlegiwinangun kurang mendapatkan informasi yang memadai terkait pengetahuan dan mitos kanker payudara.

\section{KESIMPULAN DAN SARAN}

Kanker payudara dianggap sebagai penyakit yang menakutkan yang disebabkan karena faktor keturunan, pola makan, dan perilaku yang tidak sehat. Mitos-mitos terkait kanker payudara ditemukan meski tidak sebanyak yang ada pada masyarakat luas. Mitos itu dikenal lewat proses dari mulut ke mulut, dan bukan melalui proses membaca sumber tertulis. Pengetahuan tentang kanker payudara di Desa Jlegiwinangun secara umum relatif terbatas akibat terbatasnya wawasan pengetahuan dan sumber informasi. Hal tersebut juga diakibatkan karena belum adanya upaya yang dilakukan oleh pihak-pihak berwenang dalam rangka meningkatkan pengetahuan dan kesadaran masyarakat terhadap kanker payudara. Pengetahuan yang terbatas tentang kanker payudara serta adanya mitos yang mereka ketahui belum mampu mendorong perubahan perilaku untuk pencegahan atau deteksi dini kanker payudara bagi masyarakat biasa yang bukan penderita kanker payudara.

\section{DAFTAR PUSTAKA}

1. Irianto K. Ilmu Kesehatan Masyarakat. Bandung: Alfabeta. 2014

2. World Health Organization. Cancer. [Internet]. [cited 3 Nov 2019]. Available: https://www.who.int/ cancer/en/2018

3. Kementrian Kesehatan RI. Bulan Peduli Kanker Payudara. Pusat Data dan Informasi Kementrian Kesehatan RI. 2016

4. Pusat Data dan Analisis Tempo. Kanker Payudara Seri II. Jakarta: Tempo Publishing. 2019

5. Dina Munafe, Prevalensi Kanker di Indonesia meningkat tersedia di www.beritasatu.com/ kesehatan/535688-prevalensi-kanker-di Indonesiameningkat, diakses 1 Agustus 2020

6. Kemenkes RI. Hari Kanker Sedunia 2019. [Internet]. 31 Jan 2019 [cited 3 Nov 2019]. Available: https:// www.kemkes.go.id/article/view/19020100003/harikanker-sedunia-2019.html

7. Desanti OI, Sunarsih IM, Supriyati. Persepsi Wanita Berisiko Kanker Payudara tentang Pemeriksaan Payudara Sendiri di Kota Semarang, Jawa Tengah. Berita Kedokteran Masyarakat. Vol. 26 (13) 2010:152-161

8. Sunarsih IM. Tertundanya Pengobatan Medis Pasien Kanker Payudara: Studi untuk Penyusunan Pedoman Relawan. Disertasi. Fakultas Kedokteran, Kesehatan Masyarakat dan Keperawatan UGM. 2018

9. Irianto K. Kesehatan Reproduksi Teori dan Praktikum. Bandung:Alfabeta.2015

10. YKPI. Tentang Kanker Payudara. [Internet]. [cited 3 Nov 2019]. Available: https://pitapink-ykpi.or.id/ tentang-kanker-payudara/

11. Kementrian Kesehatan RI. Panduan Program Nasional Gerakan Pencegahan dan Deteksi Dini Kanker Leher Rahim dan Kanker Payudara, Jakarta: Kementrian Kesehatan RI.2015

12. Depkes RI. Buku Saku Pencegahan Kanker Leher Rahim \& Kanker Payudara. Direktorat Jendral PP\& PL Departemen Kesehatan. 2009

13. Tim Editor, Pahami 10 Mitos dan Fakta Seputar Kanker tersedia di Htpp//kumparan.com/pahami10-mitos-dan-fakta-seputar-kanker, diakses 1 Maret 2019

14. Foster GM, Anderson BG. Antropologi Kesehatan. Jakarta: UI Press. 2009 
15. Pusat Data dan Analisis Tempo. Kanker Payudara Seri II, Jakarta: Tempo Publishing.2019

16. Dewi, G.A.T., Hendrati.L.Y. Analisis Risiko Kanker Payudara Berdasar Riwayat Pemakaian Kontrasepsi Hormonal dan Usia Menarche. Berkala Epidemiologi, Vol.3. No1, 2015:12-23

17. Haylock, P.J. Curtiss, C.P. How To Beat Cancer, Menaklukkan Rasa Nyeri Akibat Kanker dan Terapinya, Jakarta. PT Bhuana Ilmu Populer. 2006

18. Lasari, HHD, Amalia, M., Sarmila. Promosi dan Pencegahan Kanker Payudara Berbasis Media Sosial, Ponorogo: Myria Publisher.2019

19. Rio, S, Tyas-Suci, E.S. Persepsi Tentang Kanker Serviks dan Upaya Prevensinya Pada Perempuan Yang Memiliki Keluarga Dengan Riwayat Kanker, Jurnal Kesehatan Reproduksi, Vol. 4, no.3. 2017: 81-89
20. www.gleanegles.com.sg>cancer care, diakses 1 Agustus 2020

21. Notoadmojo, S. Promosi Kesehatan. Jakarta: Rineka Cipta.2007

22. Rahayuwati L, Ibrahim K, Komariah, M. Pilihan Pengobatan Pasien kanker Payudara Masa Kemoterapi:Studi Kasus. Jurnal Keperawatan Indonesia, Vol. 20 No.2, 2017:118-127.

23. Galanti, G-A . Caring for Patients from Different Cultures, Philadelphia: University Pennsylvania Press.2008

24. Arshinta Eka Putri. Ketahui Kebenaran di Balik Penyebab Kanker Yang Banyak Dipercaya Ini, tersedia di www.health.grid.id/read/351806481/ketahuikebenaran-di-balik-mitos-kanker-yang-banyakdipercaya-ini, diakses 1 Agustus 2020 